\title{
Lagosinema tenuis gen. et sp. nov. (Prochlorotrichaceae, Cyanobacteria): a new brackish water genus from Tropical Africa
}

\author{
Sandra C. AkaghA ${ }^{1,4 *}$, Jeffrey R. Johansen ${ }^{2,3}$, Dike I. Nwankwo ${ }^{1} \&$ Kedong Yin $^{4}$
}

\author{
${ }^{l}$ Department of Marine Sciences, University of Lagos, Akoka, Nigeria; *Corresponding author e-mail: san- \\ draakagha@gmail.com \\ ${ }^{2}$ Department of Biology, John Carroll University, University Heights, OH 44118 USA \\ ${ }^{3}$ Department of Botany, Faculty of Science, University of South Bohemia, Branišovská 1760, České Budějovice \\ 37005, Czech Republic \\ ${ }^{4}$ School of Marine Science, Sun Yat Sen University, Guangzhou, China
}

\begin{abstract}
A novel filamentous, nonheterocytous cyanobacterium was isolated from Lagos Lagoon, Nigeria. The isolate was $<3.0 \mu \mathrm{m}$ wide, untapered, with small rounded polar bodies (aerotopes or cyanophycin granules) visible at the crosswalls, and consequently fit the morphological description of Limnothrix planctonica. Although morphologically inseparable from that species, it was molecularly distant from that taxon, with genetic identities between the two taxa ranging $90.73-92.49 \%$, a degree of separation typical of different genera. Both taxa, as well as Limnothrix rosea, are phylogenetically in the Prochlorotrichaceae, distant from the type species of Limnothrix, L. redekei, which is in the Pseudanabaenaceae. The isolate is herein described as Lagosinema tenuis gen. et sp. nov.
\end{abstract}

Key words: 16S rRNA phylogeny, 16S-23S ITS, cyanobacteria, Lagos Lagoon, Limnothrix, Nigeria, phytoplankton, polyphasic approach, Synechococcales, taxonomy

\section{INTRODUCTION}

There are over 300 genera of cyanobacteria in current use, of which over 50 have been described since 2000 (KomÁreK et al. 2014). Most of the genera described before 2000 were found in Europe and North America and are contained in the seminal review works of GOMONT (1892), BoRnEt \& Flahault (1886-1888), and GeitLer (1932). These reviews are by nature of the cyanobacteria in temperate and subpolar climates, and they were broadly used by phycologists throughout the world to identify taxa outside of the geographic region from which they were described (e.g. Setchell 1924; YoNEDA 1938a, 1938b, 1939, 1940, 1941; LeY 1947a, 1947b, 1948; Chu 1952; Desikachary 1959; Sмith et al. 2015). Recently, many workers have posited that using European cyanobacterial literature for identification of tropical and subtropical collections on other continents fails to recognize cyanobacterial diversity, and a call has been made for modern study of cyanobacterial taxa outside of northern hemisphere temperate climate regions.

Studies of cyanobacteria using a polyphasic approach have led to discovery of novel species and genera in tropical regions. For example, a particularly active cyanobacterial research group in Brazil have described a number of new genera from the Mata Atlantica and other parts of Brazil, including Brasilonema Fiore et al. (2007), Cyanoaggregatum Werner et al. (2008), Ophiothrix SAnt'Anna et al. (2010), Streptostemon Sant'Anna et al. (2010), Cephalothrix DA SiLVA Malone et al. (2015), Halotia Genú́rio et al. (2015), Alkalinema VAZ et al. (2015), Pantanalinema VAZ et al. (2015), Dapisiostemon HentschKe et al. (2016), Komarekiella HentschKe et al. (2017), Potamolinea Martins \& Branco (2016), and Phyllonema Alvarenga et al. (2016). All of these new genera were described just in the past decade, and there is little evidence to suggest that many new additional genera will not be described from this part of the world in the near future. In the tropical Hawaiian Archepelago, four new genera were described from just five caves on the island of Kauai: Goleter Miscoe et Johansen, Kovacikia Miscoe, Pietrasiak et Johansen, Pelatocladus Johansen et Vaccarino, and Stenomitos Miscoe et Johansen (MiscoE et al. 2016). We can expect that other tropical areas, which may not yet have experienced researchers employing a combination of morphological and molecular methods, will yield similar new discoveries. 
Of the tropical regions of the world, the continent of Africa is particularly in need of modern floristic and taxonomic studies. Many floristic lists have been compiled using some of the classical literature (e.g. GEITLER 1932; Prescott 1962; DesiKachary 1959; VanLandingham 1982; WhitFORD \& SCHMACHER 1984), but since these lists do not have illustrations, it is difficult to confirm the cyanobacterial identifications given (NWANKWO \& AKINSOJI 1988; NWANKWO \& ONYEMA 2003; KADIRI, 2006; EKWU \& SiKoKi 2006; ONYEMa 2008; AdESALU \& Nwankwo 2010; Onuoha et al. 2010; AKagha \& Nwankwo 2015; Smith et al. 2015; AKagha 2017). To our knowledge, researchers have not yet undertaken molecular studies of cyanobacteria of tropical Africa.

The Lagos Lagoon is a large coastal ecosystem east of the city of Lagos, Nigeria, a city of 20 million people. It is part of the Lagos Lagoon Complex that spreads to the east (Lagos, Epe, Lekki, Kuramo, Mahin lagoons) as well as to the west (Yewa, Badagry, Ologe, Iyagbe lagoons). Several of these lagoons have received floristic study and published algal species lists (Lagos Lagoon- NWANKWO 1988, AKagha 2017; Epe Lagoon-Nwankwo 1998a, AKagha 2017; Lekki Lagoon-AdesALU \& NWANKWO 2010; Kuramo Lagoon-NwANKwo et al. 2008; Ologe Lagoon-ONUOHA et al 2010; Iyagbe Lagoon-ONYEMA 2008). Lagos Lagoon has been especially studied due to the anthropogenic impacts from the city of Lagos (AKPATA et al. 1993; NwANKWO 1995, 1998b; NwANKWO \& Adesalu 2010; NwANKwo et al. 2014). Because Lagos Lagoon is a lotic system, its trophic state varies over the period of a year based on the degree of flushing during wet and dry seasons.

As part of the ongoing study of Lagos Lagoon, we sampled diverse sites in the lagoon during August 2014 , and made a number of cyanobacterial isolations. One of our isolates bore a resemblance to Limnothrix Meffert in the possession of polar bodies resembling aerotopes, but did not fit any described species in that genus. Upon sequencing the $16 \mathrm{~S}$ rRNA gene, it was discovered that this tropical brackish water species does not belong to Limnothrix, but rather to an as yet undescribed genus and species. The purpose of this paper is to describe this genus and species, which we will refer to hereafter as Lagosinema tenuis gen. et sp. nov., based on the polyphasic approach, and thus begin the modern characterization of the cyanobacterial flora of tropical West Africa.

\section{Materials ANd Methods}

Site Description. Lagos Lagoon is shallow, brackish and the largest of the nine lagoons located in south-west Nigeria. Fresh water input from adjoining wetlands, creeks and small first-order streams as well as sea water incursion through the channel to the sea, associated with the semi-diurnal tidal regime, are important contributors to the hydrological conditions of Lagos Lagoon. Observable horizontal and vertical environmental gradients exist along the length of the lagoon because of microtidal dynamics. Domestic, municipal and industrial waste effluent empty into the lagoon through storm water channels. Human activities within the Lagos Lagoon vicinity include; indiscriminate dumping of waste, artisanal fishing, dredging, illegal sand mining, and inland water transportation. Sampling, Isolation and Characterization. Water samples were collected from the Okobaba wood waste deposition part of the Lagos Lagoon (N 6²9.462', E $3^{\circ} 23.810^{\prime}$ ) for cyanobacteria isolation. Isolations were carried out using the capillary isolation method under a compound microscope. Isolates were established in ESAW medium (BERGES et al. 2001), maintained at $25^{\circ} \mathrm{C}$, illuminated under a $12: 12 \mathrm{~h}$ light-dark cycle with an average photon flux density of $20 \mathrm{mmol}$ photons. $\mathrm{m}^{-2} \cdot \mathrm{s}^{-1}$ (warm white fluorescent lamps). Strains were characterized using an Olympus BH-2 photomicroscope with Nomarski DIC optics and an Olympus DP25 camera system with CellSens software. At least 50 trichomes and 50 cells were examined to obtain cell dimension. Cultures were examined at 2 weeks and 3 weeks after transfer.

Molecular characterization. DNA was isolated from unialgal cultures using a phenol-chloroform protocol that was modified for this study. Unialgal cultures $(20 \mathrm{ml})$ were harvested in mid to late exponential phase by centrifugation $(5,000 \mathrm{rpm}$ for 10 min at room temperature) in a sterile $50 \mathrm{ml}$ centrifuge tube. This was followed by three freeze-thaw cycles, a process that involved alternating freezing in liquid nitrogen, thawing at room temperature, and simultaneously grinding using mortar and pestle to break the cell wall to release cell contents for further enzymatic lysis. The cells were suspended in $0.5 \mathrm{ml} \mathrm{TE}$ Buffer (10 mM Tris, $1 \mathrm{mM}$ EDTA, pH 8.0) and transferred into fresh $2 \mathrm{ml}$ tubes. Thereafter, $1 \% \mathrm{SDS}$ and $50 \mu \mathrm{l}$ of $50 \mathrm{mg} \cdot \mathrm{ml}^{-1}$ lysozyme were added for enzymatic cell wall lysis. The samples were immediately incubated at $70{ }^{\circ} \mathrm{C}$ for $15 \mathrm{~min}$ to degrade the protein. The mixture was then centrifuged at $10,000 \mathrm{rpm}$ for $10 \mathrm{~min}$ at room temperature and the supernatant transferred to a fresh $1.5 \mathrm{ml}$ centrifuge tube. An equal volume of Tris phenol was added and centrifuged at $12,000 \mathrm{rpm}$ for $10 \mathrm{~min}$ at $4{ }^{\circ} \mathrm{C}$. The supernatant was transferred into a $1.5 \mathrm{ml}$ centrifuge tube. The nucleic acid was thereafter isolated by adding an equal volume of phenol: chloroform: isoamyl alcohol (25:24:1, Sigma-Aldrich, St. Louis, Missouri) and then centrifuged at $12,000 \mathrm{rpm}$ for $10 \mathrm{~min}$ at $4{ }^{\circ} \mathrm{C}$. The supernatant was transferred into a fresh tube and twice the volume of iced absolute ethanol stored at $-20^{\circ} \mathrm{C}$ was added. The mixture was frozen at $-80^{\circ} \mathrm{C}$ for $30 \mathrm{~min}$, centrifuged at $15,000 \mathrm{rpm}$ for $30 \mathrm{~min}$ at $10^{\circ} \mathrm{C}$ and the supernatant was discarded. The DNA pellet was washed by adding $1 \mathrm{ml}$ of cold $70 \%$ ethanol, centrifuged at 12,000 rpm for $10 \mathrm{~min}$ at $4{ }^{\circ} \mathrm{C}$ and the supernatant was discarded. The DNA pellet was air dried before being suspended in $100 \mu \mathrm{l}$ TE Buffer (10 mM Tris, 1 mM EDTA, pH 8.0).

Two separate polymerase chain reaction amplifications were conducted. The first amplified a long partial sequence of the 16S rRNA gene, using primers 27F and 1492R (LANE 1991). The amplified products were run in a Takara PCR thermal cycler (Takara Holdings, Kyoto, Japan) using the following PCR cycle: $94{ }^{\circ} \mathrm{C}$ for 5 min followed by 34 cycles of: denaturation temperature of $94{ }^{\circ} \mathrm{C}$ for $30 \mathrm{~s}$, annealing temperature of $55^{\circ} \mathrm{C}$ for $30 \mathrm{~s}$, and elongation temperature of $72^{\circ} \mathrm{C}$ for $90 \mathrm{~s}$; ending in an additional 5 min elongation at $72{ }^{\circ} \mathrm{C}$, and finally an indefinite hold at $16^{\circ} \mathrm{C}$. The amplified product was directly sequenced. The second set of PCR amplifications recovered a smaller fragment of the 16S rRNA gene and the full 16S-23S ITS region using primer VF1 and primer VF2 sensu BOYER et al. (2001, 2002), based on the original primers of WiLMOTTE et al. (1993) and NüBEL et al. (1997). The amplified products were run 
in a $\mathrm{C} 1000$ Thermocycler (BIORAD) using the following PCR cycle: $95^{\circ} \mathrm{C}$ for $5 \mathrm{~min}$ followed by 35 cycles of: denaturation temperature of $95{ }^{\circ} \mathrm{C}$ for $1 \mathrm{~min}$, annealing temperature of 57 ${ }^{\circ} \mathrm{C}$ for $45 \mathrm{~s}$, and elongation temperature of $72{ }^{\circ} \mathrm{C}$ for $4 \mathrm{~min}$; ending in an additional 5 min elongation at $72{ }^{\circ} \mathrm{C}$, and finally an indefinite hold at $4{ }^{\circ} \mathrm{C}$. All PCR products were visualized on $1 \%$ agarose gel and cloned into the $\mathrm{pSC}-\mathrm{A}-\mathrm{amp} / \mathrm{kan}$ plasmid of the StrataClone PCR Cloning kit (La Jolla, California, USA). The clones were isolated using QIAprep Spin kit from QIAGEN (Venlo, The Netherlands) with elution in $50 \mu$ of sterile water. The presence of an insert was confirmed by EcoRI digestion. Plasmids containing inserts were sent for sequencing to Functional Biosciences, Inc. (Madison, Wisconsin, USA). We used the sequencing primers M13 forward, M13 reverse and internal primers 3, 5 and 8 (Boyer et al., 2001, 2002). Sequences within strains were aligned and assembled using Sequencher v. 4.10.1 (Gene Codes Corporation, Ann Arbor, Michigan). Alignments of multiple strains were made with a combination of ClustalW and manual alignment informed by secondary structure. After alignment, the data were converted to a nexus file for phylogenetic analysis.

Phylogenetic Analysis. To determine phylogenetic placement of Lagosinema tenuis, consensus sequences of the 16S rRNA gene (1199 nucleotides) were aligned with other sequences available in GenBank. These sequences were chosen using either Blast Search against our sequences, or by their identification with genera in the order Synechococcales. In total, this alignment of the $16 \mathrm{~S}$ rRNA gene contained 313 sequences including Gloeobacter violaceus RIPPKA, WATERBURY \& COHEN-BAZIRE (1974) as an outgroup. Bayesian inference, maximum likelihood, and maximum parsimony analyses were then performed on this alignment.

Bayesian inference (BI) analysis was conducted with MrBayes XSDE V3.2.6 (RoNQUIST et al. 2012) through the CIPRES Science Gateway, applying the GTR $+\mathrm{G}+\mathrm{I}$ model of nucleotide substitutions. A total of 38 million generations were run. The Bayesian analysis had an estimated sample size (ESS) exceeding 920 for all parameters (average ESS ranging 975-20,550), well above the average of 200 typically accepted as sufficient by phylogeneticists (DRUMMOND et al. 2006). The final average standard deviation of split frequencies was 0.010 The potential scale reduction factor (PSRF) value for all the estimated parameters in the Bayesian analysis was 1.00 , indicating that convergence of the MCMC chains was statistically achieved (GELMAN \& RUBIN 1992). Maximum Likelihood (ML) analysis was run using RAxML-HPC v.8 on XSEDE available through the CIPRES Science Gateway v. 3.3. Maximum Likelihood was run using the GTR $+\mathrm{I}+\mathrm{G}$ model, with 1000 bootstrap replicates. Maximum Parsimony (MP) analysis was run using PAUP (SWOFFORD 1998), version $4 b .10$, with a heuristic search with steepest $=y e s$, multrees $=$ no, swap $=$ TBR, nreps $=1000$, with a subsequent bootstrap analysis with nreps $=1000$.

Trees were viewed using FigTree (Rambaut 2007). The Bayesian Inference analysis was reported herein with bootstrap values for the ML and MP analysis mapped on to the $\mathrm{BI}$ tree. The final composite tree was re-drawn using Adobe Illustrator CS5.1 (Adobe Systems, San Jose, California). Pdistance of $16 \mathrm{~S}$ sequences was determined in PAUP to reveal similarity among our strains of interest (SWOFFORD 1998). The hypothetical ITS secondary structures of helices D1-D1, Box-B, and V3 were derived using M-fold (ZuKER 2003) and re-drawn in Adobe Illustrator CS5.1.

\section{RESULTS}

\section{Lagosinema Akagha et Johansen gen. nov.}

Description: Filaments solitary, lacking sheath material. Trichomes motile, without branching, straight to curved, flexuous, thin, less than $3 \mu \mathrm{m}$ in diameter. Hormogonia formed by simple fragmentation without necridia. Cells nongranular or with colored elongated granules, with polar bodies resembling aerotopes typically at crosswalls, with parietal thylakoids.
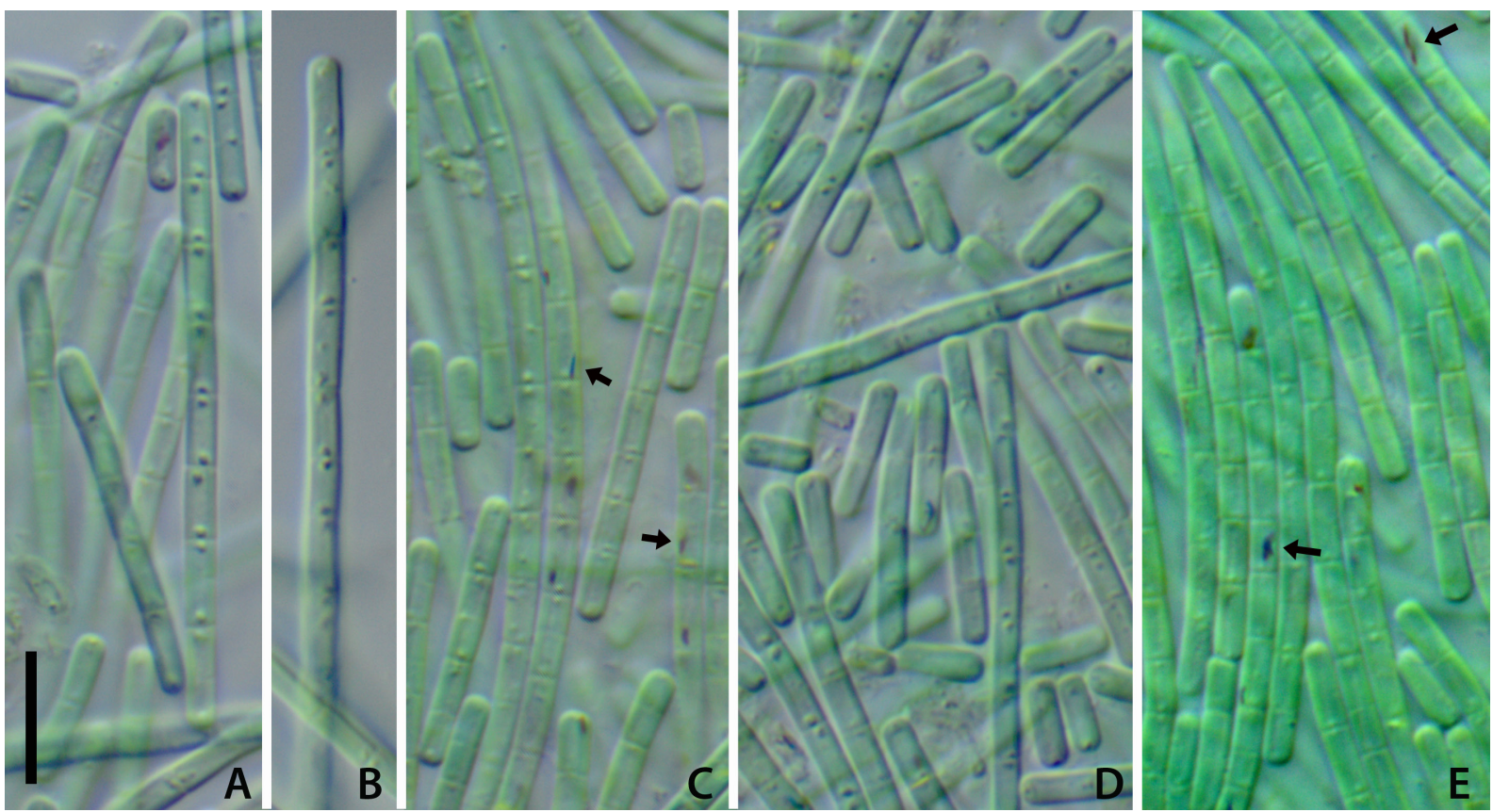

Fig. 1. Lagosinema tenuis LM photomicrographs. Arrows: bluish and brownish crystalline bodies. Scale $10 \mu \mathrm{m}$. 
Type species: Lagosinema tenuis Akagha et Johansen sp. nov.

Etymology: Lagosinema $=$ Lagos - site of origin + nema (GR)-filament.

\section{Lagosinema tenuis Akagha et Johansen sp. nov. (Fig.} 1, 2)

Description: Thallus in young cultures a thin mat coating the walls and bottom of culture vessel, later forming a floating mat, consistently pale blue-green. Sheaths always absent. Trichomes motile, straight to sinuous, flexuous, not coiled, without false branching, not constricted to slightly constricted at the crosswalls, $2-2.5 \mu \mathrm{m}$ wide. Hormogonia form by simple fragmentation, without necridia, as short as a single cell in length. Cells nongranular or possessing elongate bluish and brownish granules, often with polar bodies resembling aerotopes at the crosswalls, with parietal thylakoids which are detectable in some cells as the presence of peripheral chromatoplasm, dividing by simple binary fission and achieving full length before next division, not in meristematic zones, 3.2-7.5 $\mu \mathrm{m}$ long. Apical cells cylindrical with rounded apices, not different in length or morphology from internal cells.

Type Locality: Lagos Lagoon, Okobaba (wood waste dump site), N $6^{\circ} 29.462^{\prime}$, E $3^{\circ} 23.810^{\prime}$, in brackish (15-20\%) water, sampled August 2014.

Holotype here designated: BRY37768, Herbarium for Nonvascular Cryptogams, Monte L. Bean Museum,

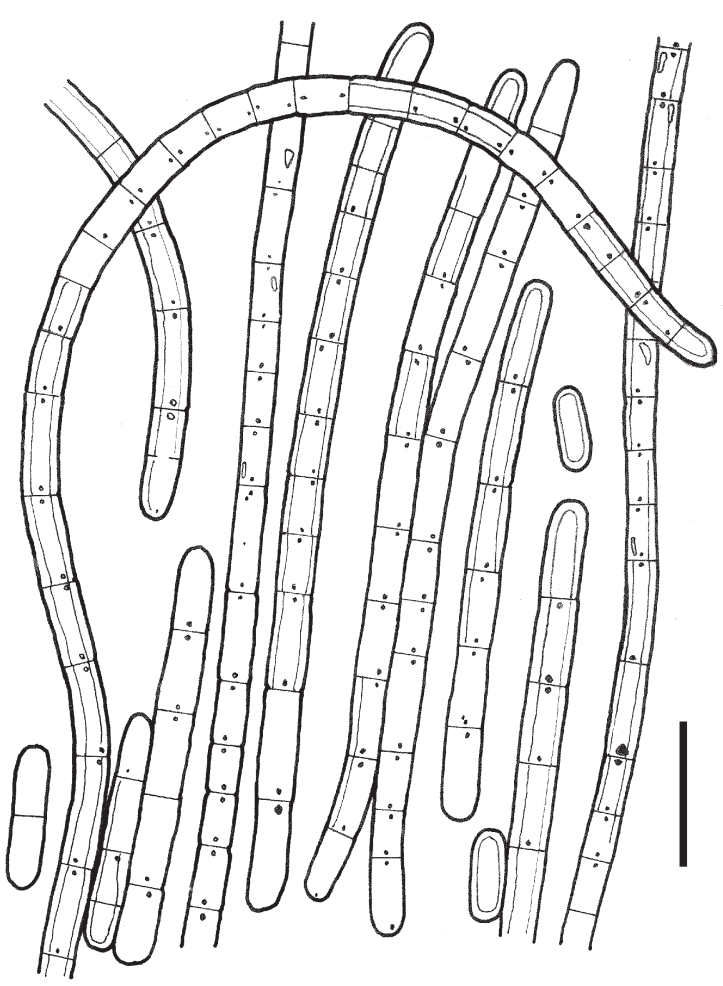

Fig. 2. Lagosinema tenuis line drawings based on selected filaments from numerous photomicrographs. Scale $10 \mu \mathrm{m}$.
Brigham Young University, Provo, Utah.

\section{Reference strain: NGPC151}

Etymology: tenuis (L) = thin, named for thin width of trichomes.

\section{Analysis of Molecular Data}

In all analyses conducted, Lagosinema was sister to a large clade of strains assigned to Limnothrix sp., $L$. planctonica (Woloszyńska) Meffert, and L. redekei (Goor) Meffert (Fig. 3). This clade of putative Limnothrix strains is well studied, and many have been illustrated and found to contain small polar aerotopes (ZHU et al. 2012). The reference strain for $L$. redekei, the type species for Limnothrix, is PCC 9416 (=SAG 3.89, originally isolated by Marie-Elisabeth Meffert from Eastholstein), and the short 16S rRNA partial sequence associated with this strain is most similar (100\% identity) to the L. redekei strains in the Pseudanabaenaceae at the base of our phylogeny, CCAP 1443/1 and NIVA-CYA 227/1 (Fig. 3). This indicates that the L. planctonica clade of ZHU et al. (2012) contains strains that cannot belong to Limnothrix sensu stricto, and they will need to be transferred into another, new genus at some future time. Limnothrix rosea Meffert IAM-M220 falls out side of Limnothrix sensu stricto, L. planctonica, and Lagosinema tenuis, and is consequently in a genus separate from these three taxa. Lagosinema, L. planctonica, and L. rosea strains all fall into a family level clade that includes Prochlorothrix Burger-Wiersma, Stal et Mur, Halomicronema Abed, Garcia-Pichel et Hernández-Mariné, and Nodosilinea (Z. Li et J.Brand) Perkerson et Casamatta (1.0 BI posterior probability, $83 \%$ ML bootstrap support). Prochlorothrix was described under the International Bacteriological Code of Nomenclature and placed in the family Prochlorotrichaceae (BURGER-WIERSMA et al. (1989). We consequently place Lagosinema in the family Prochlorotrichaceae.

The $\mathrm{p}$-distance based on 16S rRNA gene between Lagosinema tenuis and all members of the L. planctonica clade was $0.0751-0.0927$ (Table 1), or 90.73-92.49\% genetic identity. This level of sequence similarity is well below the $94.5 \%$ identity level most recently recommended as a cut-off value justifying recognition of separate bacterial genera (STACKEBRANDT \& GOEBEL 1994; StACKEBRANDT \& EBERS 2006; KIM et al. 2014; YARZA et al. 2014). It was not more similar to any other set of sequences in the Prochlorotrichaceae. The low genetic identity alone provides sufficient evidence to separate Lagosinema from all other Prochlorotrichaceae.

We recovered two ribosomal operons from $L$. tenuis NGPC151 based on the differences noted in the $16 \mathrm{~S}-23 \mathrm{~S}$ ITS. The ITS regions of the two operons had percent dissimilarity $=10.8 \%$, a level high enough to rule out PCR error. The D1-D1' and Box-B helices of the two operons were identical in structure, even with a few nucleotides different in both (Figs 4 A, 5 A, B). The V3 helices differed in structure and sequence within strain NGPC151 (Fig. 6 A, B). The ITS structures 
Table 1. Comparison of percent genetic identity based on 16S RRNA gene sequence among taxa phylogenetically related to Lagosinema tenuis. Cyanobium NGPC10GR and Synechococcus MBIC10598 are representatives of the Nodosilinea/Halomicronema group in Fig. 6. Oscillatoria rosea is an earlier synonym of Limnothrix rosea.

\begin{tabular}{|c|c|c|c|c|c|c|c|c|c|}
\hline Strain & 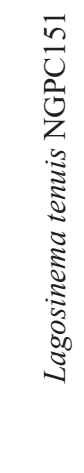 & 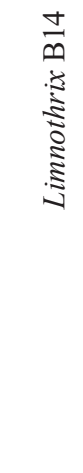 & 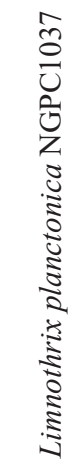 & 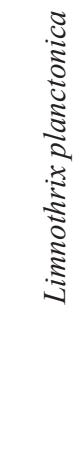 & 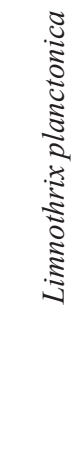 & 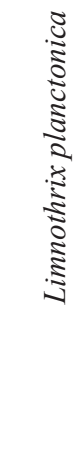 & 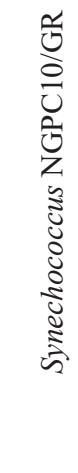 & 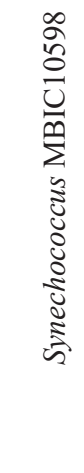 & 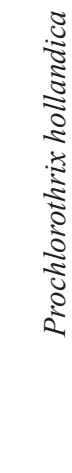 \\
\hline Lagosinema tenuis NGPC151 & - & & & & & & & & \\
\hline Limnothrix B14 & 92.5 & - & & & & & & & \\
\hline Limnothrix planctonica NGPC10/37 & 92.4 & 98.6 & - & & & & & & \\
\hline Limnothrix planctonica JQ004021 & 92.3 & 98.5 & 99.9 & - & & & & & \\
\hline Limnothrix planctonica JQ004025 & 92.5 & 98.5 & 99.9 & 99.8 & - & & & & \\
\hline Limnothrix planctonica GQ859647 & 90.7 & 95.3 & 95.9 & 95.8 & 95.9 & - & & & \\
\hline Synechococcus NGPC10GR & 89.5 & 89.9 & 90.7 & 90.6 & 90.7 & 89.4 & - & & \\
\hline Synechococcus MBIC10598 & 89.4 & 89.7 & 90.1 & 90.0 & 90.1 & 88.6 & 90.7 & - & \\
\hline Prochlorothrix hollandica & 89.8 & 81.2 & 91.6 & 91.5 & 91.6 & 90.1 & 90.3 & 91.4 & - \\
\hline Limnothrix rosea IAM-M220 & 88.9 & 89.2 & 89.5 & 89.4 & 89.4 & 87.6 & 87.6 & 90.9 & 90.2 \\
\hline
\end{tabular}

Table 2. Nucleotide lengths for conserved domains in the 16S-23S ITS region of Lagosinema tenuis, closest relatives in the Prochlorotrichaceae (L. planctonica, P. hollandica, H. hongdechloris, L. rosea, Prochlorotricaceae Gollwitz, and Nodosilinea nodulosa), and more distantly related Pseudanabaenaceae (Limnothrix redekei). For operons lacking the tRNA ${ }^{\text {Ala }}$ gene, the spacer following the tRNA ${ }^{\text {Ile }}$ gene extends to the Box B helix. H. hongdechloris lacked a D3 concensus sequence. We are unsure that the L. planctonica sequences were complete at the 3' end of the sequence available.

\begin{tabular}{|c|c|c|c|c|c|c|c|c|c|c|c|c|c|c|}
\hline Strain & 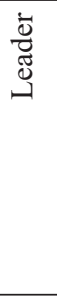 & 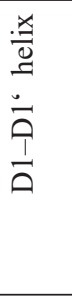 & 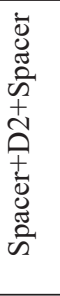 & 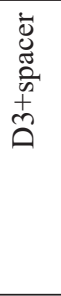 & 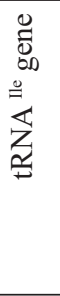 & 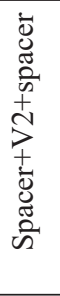 & 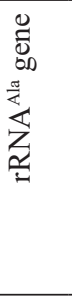 & $\begin{array}{l}\overline{\bar{\delta}} \\
\tilde{\tilde{E}} \\
\tilde{\tilde{n}}\end{array}$ & 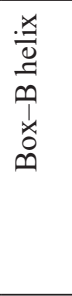 & $\begin{array}{l}\overline{\tilde{J}} \\
\tilde{\tilde{0}} \\
\tilde{n}\end{array}$ & $\begin{array}{l}\ll \\
\check{x} \\
0\end{array}$ & $\begin{array}{l}\dot{\bar{J}} \\
\tilde{\tilde{J}} \\
\tilde{0} \\
\pm \\
\dot{0} \\
\dot{0}\end{array}$ & 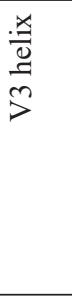 & 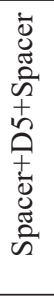 \\
\hline Lagosinema tenuis NGPC151 cl4 & 7 & 63 & 70 & 14 & 74 & & 57 & & 30 & 17 & 11 & 33 & 114 & 30 \\
\hline Lagosinema tenuis NGPC151 cl6 & 7 & 63 & 70 & 14 & 74 & & 57 & & 31 & 17 & 11 & 32 & 114 & 30 \\
\hline Limnothrix planctonica KLL clA & 7 & 63 & 35 & 28 & 74 & & 93 & & 29 & 17 & 11 & 31 & 41 & - \\
\hline Limnothrix planctonica KLL clC & 7 & 63 & 35 & 38 & 74 & & 115 & & 38 & 17 & 11 & 31 & 41 & - \\
\hline Prochlrothrix hollandica & 7 & 107 & 38 & 29 & 74 & 13 & 73 & 231 & 36 & 17 & 11 & 31 & 116 & 75 \\
\hline Halomicronema hongdechloris & 7 & 59 & \multicolumn{2}{|c|}{42} & 74 & 72 & 73 & 17 & 34 & 18 & 11 & 48 & NA & 6 \\
\hline Limnothrix rosea & 7 & 65 & 37 & 13 & 74 & 46 & 73 & 24 & 33 & 18 & 11 & 36 & 38 & 28 \\
\hline Prochlorotrichaceae Gollwitz Pohl & 7 & 57 & 37 & 12 & 74 & 6 & 73 & 32 & 35 & 20 & 11 & 27 & 50 & 20 \\
\hline Nodosilinea nodulosa UTEX 2910 & 7 & 62 & 33 & 71 & 74 & 6 & 73 & 24 & 40 & 17 & 11 & 65 & 26 & 2 \\
\hline Limnothrix redekei CCAP 1443/1 & 7 & 63 & 36 & 21 & 74 & 38 & 73 & 40 & 47 & 36 & 11 & 32 & 10 & 3 \\
\hline
\end{tabular}


in Lagosinema were very different from those in other Prochlorotrichaceae, another indication of evolutionary distance (Figs 4-6). Of special note was the presence of only a single tRNA gene (tRNA ${ }^{\mathrm{Ile}}$ ) in the ITS region. This pattern occurs in other cyanobacteria, but it is rarer than either two tRNA genes or none. The sister taxon, L. planctonica, likewise had only had the tRNA ${ }^{\text {Ile }}$ gene, but all other Prochlorotrichaceae had both tRNA ${ }^{\text {Ile }}$ and tRNA $^{\mathrm{Ala}}$ (Table 2).

The Prochlorotrichaceae had a number of unusual patterns in the ITS region. Halomicronema hongdechloris Chen, Li, Birch et Willows lacked a D3 region (consensus sequence 5'-GGTTC-3', after the D2 region and before the tRNA ${ }^{\text {lle }}$ gene, see JOHANSEN et al. 2017), the only instance we know of this absence in cyanobacteria. Limnothrix planctonica, L. redekei, $H$. hongdechloris, and N. nodulosa (Z. Li et J. Brand) Perkerson et Casamatta all lacked a D5 helix (Table 2 ). This lack of the D5 occurs only very seldom in the cyanobacteria. The D1-D1' helix and spacer following tRNA $^{\text {Ala }}$ in Prochlorothrix and the V3 helix in Lagosinema and Prochlorothrix were unusually long (more than 100 nt each, see Table 2).

\section{Discussion}

In the original description of Limnothrix, MEFFERT (1988) transferred three species into the new genus: Oscillatoria redekei Goor, Oscillatoria planctonica Woloszysińska, and Oscillatoria rosea Utermöhl. The taxonomic transfer was the conclusion of a long series of papers on these thin, aerotope producing taxa which detailed aspects of the lifecycle and ultrastructure as visualized in LM and TEM (MeFFERT 1971; MeFFERT \& KRAMBECK 1977; MeFFERT \& Chang 1978; MefFert \& Overbeck 1981; MefFert 1987; MEFFERT \& OBERHÄUSER 1982). Limnothrix redekei, the type species for the genus, is difficult to maintain in culture without special treatment (MEFFERT 1972, 1973a, $1973 \mathrm{~b}$ ), and this has led to its loss from some culture collections. The reference strain, SAG 3.89-originally CCAP1443/3, still exists in the SAG collection, and a short ribosomal sequence exists (NCBI AJ544070, 489 nt). This sequence is $100 \%$ identical to another short sequence, PMC8502 (NCBI AJ544069, 489 nt) and a long sequence, CCAP1443/1 (NCBI AJ580007, 2431 $\mathrm{nt}$ ), a strain originally isolated and studied by MEFFERT. There is little doubt that this set of strains, together with NIVA-CYA227/1, all belong to the same species and genus, and could be considered reference strains of $L$. redekei. This is significant because other strains have been assigned to $L$. redekei and sequenced, and they are undoubtedly incorrectly identified; they occur in the $L$. planctonica clade (Fig. 3) and should be reassigned to that species. L. planctonica differs from L. redekei in that its polar aerotopes are much smaller and more spherical. Lagosinema tenuis bears a strong resemblance to $L$. planctonica in that it shares the small spherical polar bodies (Figs 1, 2). The nature of these polar bodies is unclear in the LM. ZHU et al. (2012) observed polar bodies that were iridescent and clearly aerotopes in $L$. planctonica in the light microscope in fresh material, but in TEM of cultures they did not observe aerotopes, but rather saw spherical granules that are more likely cyanophycin granules. Due to this ambiguity in the sister taxon of Lagosinema, we are uncertain at this time whether they have aerotopes, cyanophycin granules, or the possibility of either at the poles of the cells. L. tenuis was collected from the plankton of the water column, suggesting the presence of aerotopes, but at this time we refer to them simply as polar bodies in the formal description of the taxon.

MaI et al. (2018) split the Leptolyngbyaceae into four families. Leptolyngbyaceae and Prochlorotrichaceae were existing families, and Oculatellaceae and Trichocoleaceae were described as new families. The Pseudanabaenaceae was outside of Leptolyngbyaceae sensu lato in a basal position sister to Gloeobacter violaceus. The phylogeny in this work supported their analysis, with the same family level clades being apparent.

Limnothrix planctonica and L. rosea are both in the Prochlorotrichaceae, and are in separate generic clades from each other and from Lagosinema. They both clearly are neither Lagosinema or Limnothrix, and must be eventually placed in their own genera. Limnothrix redekei is itself in jeopardy. WhITTON (2011 p. 110) attempted to transfer $L$. redekei to Pseudanabaena redekei (Goor) Whitton, but the transfer was invalid due to incorrect pagination of the basionym citation (in violation of ICN Article 41.5 and Note 1 under 41.5). L. redekei lies within the Pseudanabaena Lauterborn clade as it is presently defined, and may eventually be transferred into Pseudanabaena. Alternatively, the subgenera in Pseudanabaena may be raised to genus level, in which case Limnothrix might retain its taxonomic status.

Our phylogenetic analysis demonstrates the need for considerable taxonomic work in the Prochlorotrichaceae. In addition to the L. planctonica and L. rosea clades, the following clades need corrected generic definition: 1) clade containing Phormidium persicinum Gomont (3 OTUs), 2) Oscillatoriales Gollwitz Pohl, 3) Leptolyngbya PCC 6406, 4) clade containing LPP group MBIC 10597 (6 OTUs), and 5) Leptolyngbya WJT66-NPBG5. In addition to these seven new genera (which will also require description of the species), the genus Nodosilinea now has many sequenced strains that have not been identified to species. Many new species of Nodosilinea will subsequently be described. This work on Nodosilinea has already commenced (HEIDARI et al. 2018; VÁzQUEZMARTÍNEZ et al. 2018)

The confusion surrounding Limnothrix is likely due to the broad characterization of the genus: filaments less than 1-6 $\mu \mathrm{m}$, untapered, with polar or central aerotopes (KomÁreK \& AnAgnostidis 2005). L. bicudoi Azevedo et C.A. de Souza, L. redekei, and L. vacuolifera (Skuja) Komárek ex McGregor possess enlarged, often irregular, 


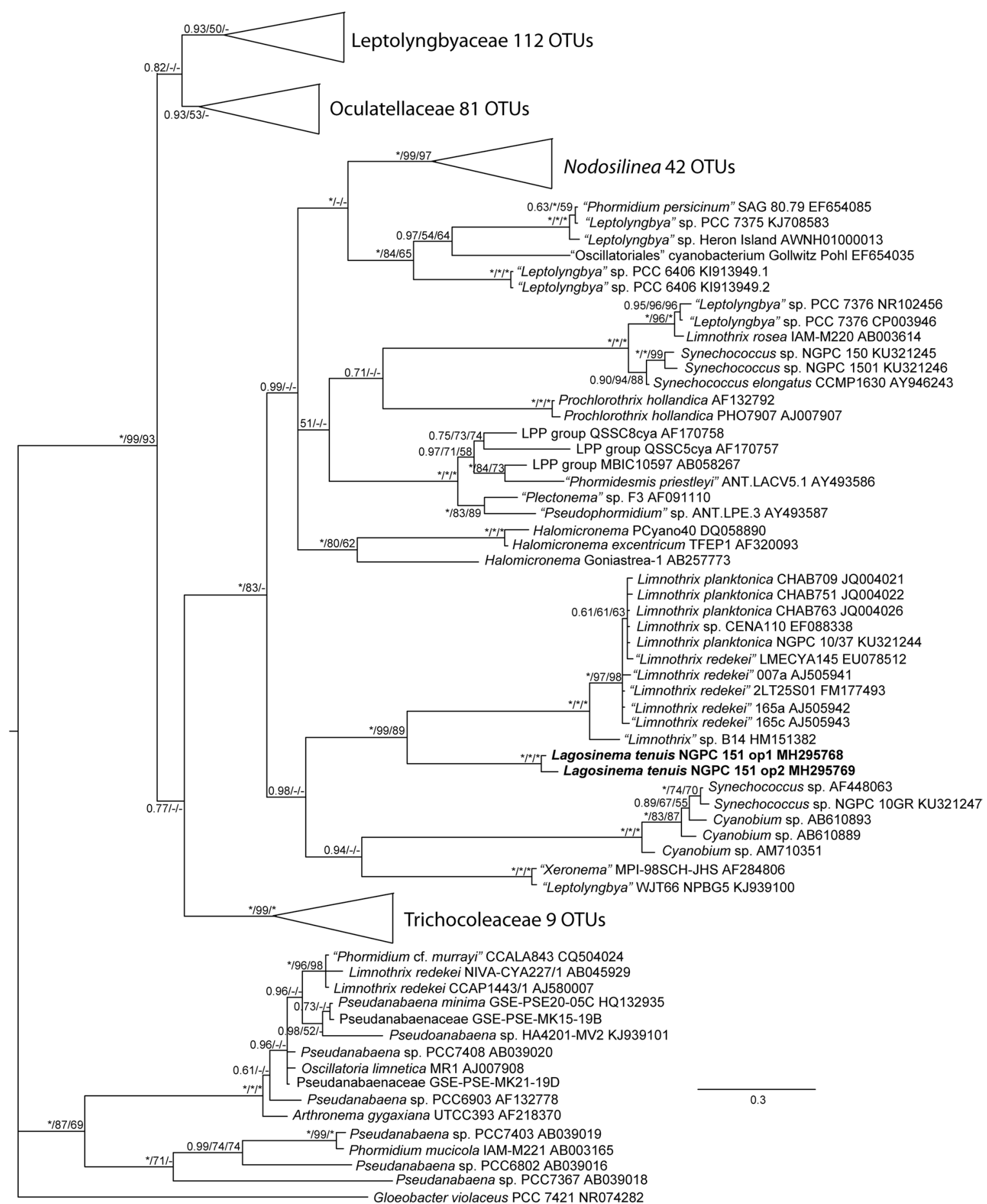

Fig. 3. Bayesian Inference phylogeny based on 313 partial sequences of the 16S rRNA gene (1199 nucleotide positions) showing structure within the Prochlorotrichaceae and Pseudanabaenaceae. Support values at nodes represent BI/ML/MP posterior probabilities/bootstrap values. Full support is indicated by an “*” (1.0 or 100\%), less than $0.50 / 50 \%$ support indicated by "-". Taxa which we consider to be incorrectly identified or needing taxonomic revision are set off in quotation marks.

polar aerotopes, and may represent Limnothrix sensu stricto. The taxa with distinctive, large, central aerotopes may comprise another genus; these types include $L$. borgertii (Lemmermann) Anagnostidis, L. brachynema (Skuja) Hindák et Trifonova, L. hypolimnetica Hindák et Trifonova, L. lauterbornii (Schmidle) Anagnostidis, $L$. pseudospirulina (Pascher) Anagnostidis, L. pseudovacuolata (Utermöhl) Anagnostidis, and L. rosea. Limnothrix planctonica was illustrated by both MeFFERT (1988) and ZHU et al. (2012) as having small rounded polar aerotopes. Komárek \& Anagnostidis (2005) indicate both in their key and description that $L$. planctonica has a single central aerotope, although their pictures show the aerotopes as being confined to the crosswalls (i.e., polar). L. planctonica and L. tenuis are indistinguishable based on morphology. They are what would certainly be 


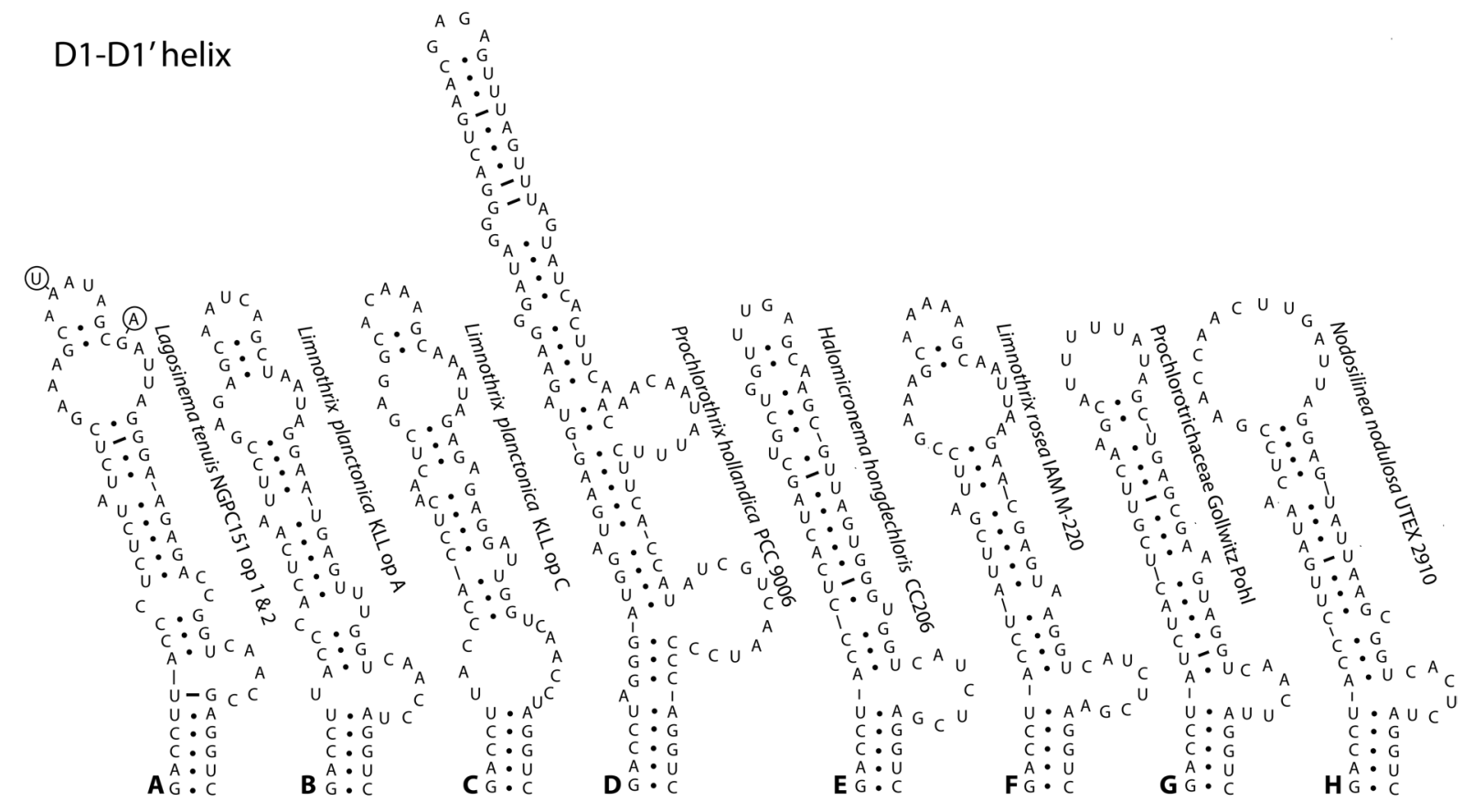

Fig. 4. Secondary structure of the D1-D1' helix in Lagosinema and representative Prochlorotrichaceae for which 16S-23S ITS sequence data are available. Circled bases in L. tenuis represent base pair differences between the different operons. L. planctonica also had two operons, but the D1-D1' helices differed in structure between the two operons of that taxon.

\section{Box-B helix}

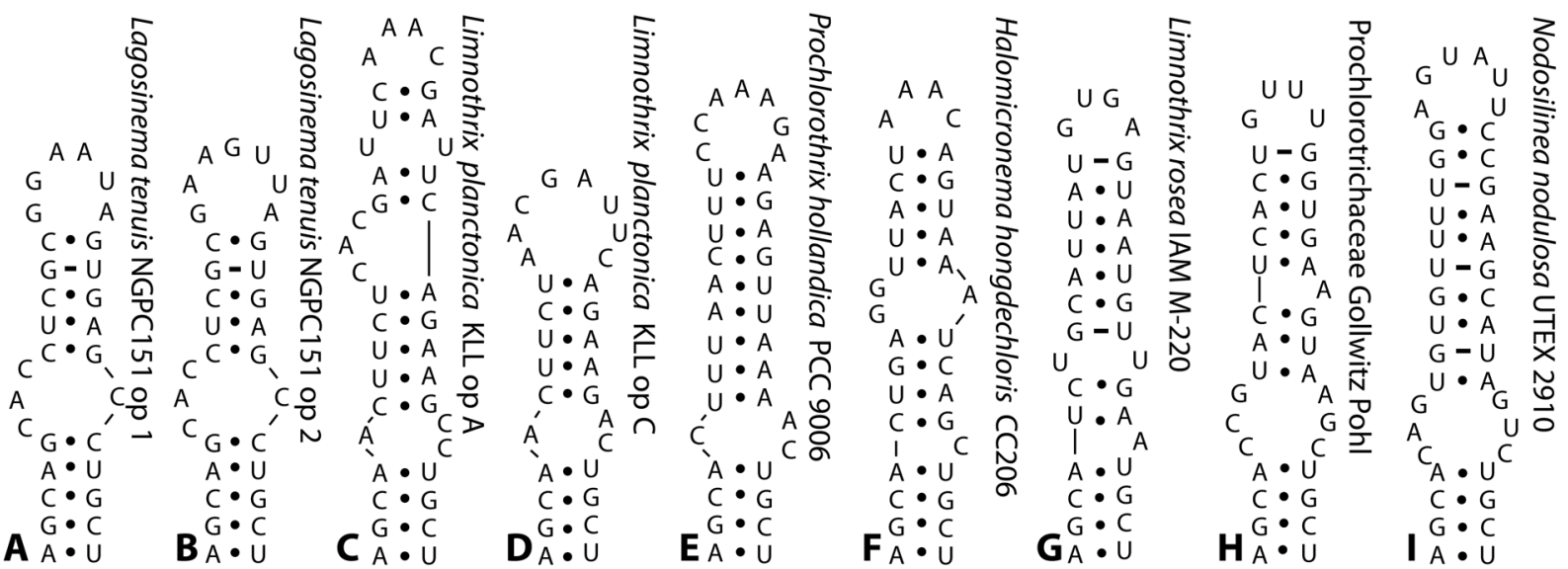

Fig. 5. Secondary structure of the Box-B helix in Lagosinema and representative Prochlorotrichaceae for which 16S-23S ITS sequence data are available. Note the differences between the bilateral bulges just above the basal clamp sequence (5'-AGCA:UGCU-3'), consistent with the conclusion that these taxa are all in separate genera.

considered cryptogenera (KoMÁREK et al. 2014).

The Synechococcales contains a great number of molecularly and morphologically divergent taxa. Seventy-four genera were recognized in the order in the newest taxonomic system (KOMÁreK et al. 2014), with (counting Lagosinema) 18 additional genera being published since that treatment (Dvořák et al. 2015; SONG et al 2015; VAZ et al. 2015; Li \& Li 2016; MiscoE et al. 2016; SCIUTO \& Moro 2016; DvoŘAK et al. 2017; JAHODÁŘOvÁ et al. 2017a, 2017b; SCIUTO et al. 2017; MAI et al. 2018). Furthermore, there are numerous unnamed or incorrectly named sequenced species that appear in our phylogenetic analysis that certainly need to be placed in new genera if genera are to become monophyletic taxa (Fig. S1). There is a great deal of $\alpha$-level taxonomy remaining to be completed in the order, and the next few years will likely see many efforts to expand the taxonomy of this group so that it conforms with modern species and generic concepts. We look forward to both seeing and being a part of this work.

\section{ACKNOWLEDGEMENTS}

This work was supported by the Organization for Women in 

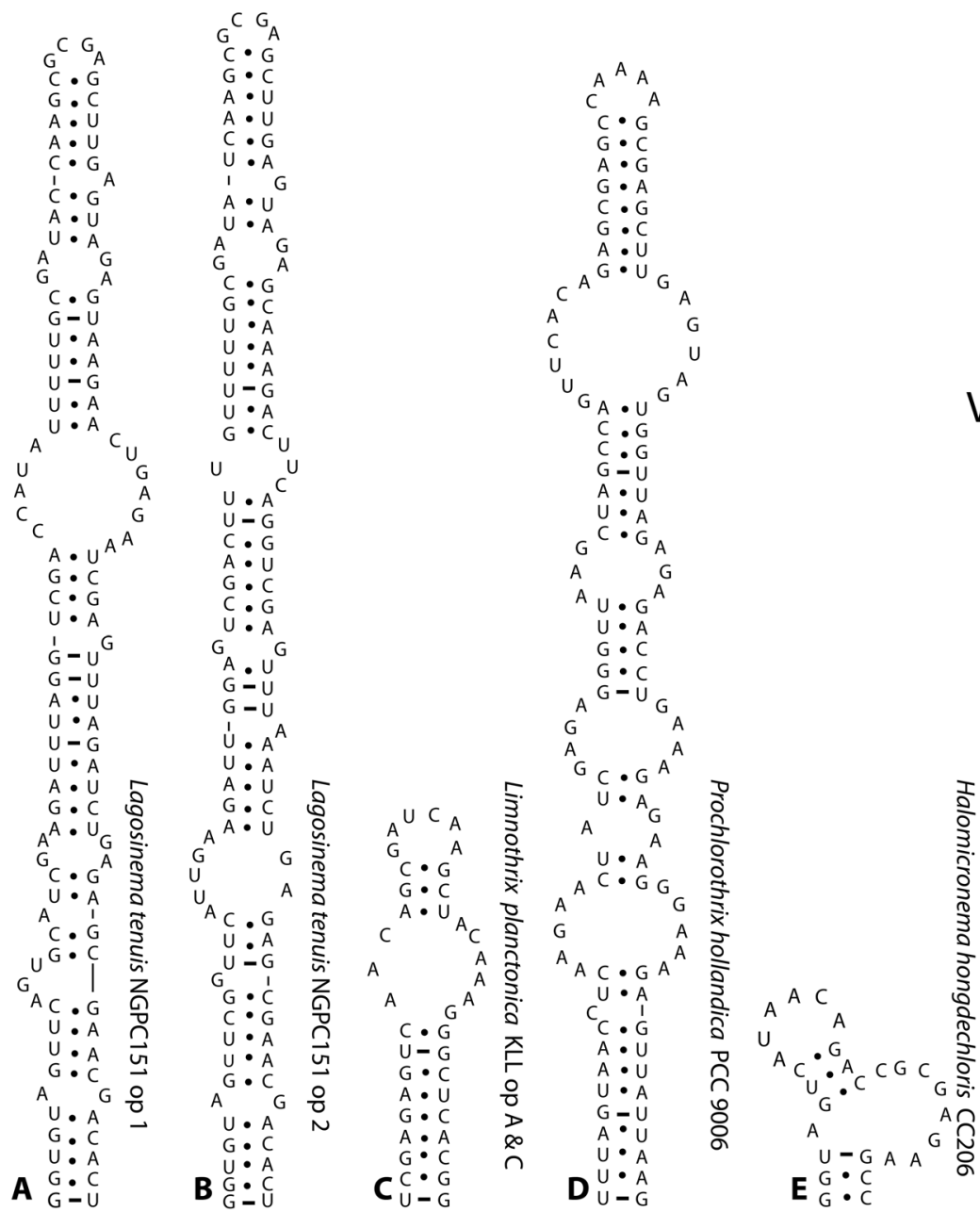

\section{V3 helix}

Fig. 6. Secondary structure of the V3 helix in Lagosinema and representative Prochlorotrichaceae for which 16S-23S ITS sequence data are available. Note the structural dissimilarity between the V3 helices of the two different operons of $L$. tenuis, and the identical nature of the V3 helices in L. planctonica, sister taxon to Lagosinema. The notable divergence in length and structure of the V3 helix is unusual for cyanobacterial genera belonging to the same family.

Science for the Developing World (OWSD) and the Swedish International Development Cooperation Agency (Sida) postgraduate training fellowship to Sandra C. Akagha (Grant No. 3240274102). Jeffrey R. Johansen was funded in part by grant No. 15-11912S from the Czech Science Foundation and in part by institutional support from John Carroll University. We thank Michael Guiry for providing insights on the validity of names surrounding Limnothrix redekei and Prochlorothrix and Maike Lorenz for providing a history of Limnothrix strains.

\section{REFERENCES}

Adesalu, T.A. \& Nwankwo, D.I. (2010): Cyanobacteria of a Tropical Lagoon, Nigeria. - J. Am. Sci. 6: 1101-1107.

Akagha, S.C. (2017): Phytoplankton of tropical lagoons. Nigerian J. Bot. 30: 253-276.

Akagha, S.C. \& Nwankwo, D.I. (2015): Studies on the primary productivity of a polluted mangrove pond in Lagos, Nigeria. - J. Aqua. Sci. 30: 337-351.

AKPATA, T.V.I.; OYENEKAN, J.A. \& NWANKO, D.I. (1993). Impact of organic pollution on the bacterial plankton and benthic populations of Lagos Lagoon, Nigeria. - Int.
J. Ecol. Environ. Sci. 17: 1-10.

Alvarenga, D.; Rigonato, J.; Branco, L.; Melo, I. \& Fiore, M. (2016): Phyllonema aviceniicola gen. nov., sp. nov. and Foliisarcina bertiogensis gen. nov., sp. nov., epiphyllic cyanobacteria associated with Avicennia schaueriana leaves. - Int. J. Syst. Evol. Microbiol. 66: 689-700.

Berges, J.A.; FrankLin, D.J. \& Harrison, P.J. (2001): Evolution of an artificial sea water medium: Improvements in enriched seawater, artificial water over the past two decades. - J. Phycol. 37: 1138-1145.

Bornet, E. \& Flahault, C. (1886-1888): Revision des Nostocacées hétérocystées. - Ann. Sci. Nat. Bot. 7 Sér. 3:323-81, 4:343-73, 5:51-129, 7:177-262 [Reprint 1959, J. Crammer, Weinheim].

BOYer, S.L.; FleChTNER, V.F. \& JOHANSEn, J.R. (2001): Is the 16S-23S rRNA internal transcribed spacer region a good tool for use in molecular systematics and population genetics? A case study in cyanobacteria. - Mol. Biol. Evol. 18: 1057-1069.

Boyer, S.L.; Johansen, J.R.; Flechtner, V.R. \& Howard, G.L. (2002): Phylogeny and genetic variance in terrestrial Microcoleus (Cyanophyceae) species based on sequence analysis of the 16S rRNA gene and associated 
16S-23S ITS region. - J. Phycol. 38: 1222-1235.

Burger-Wiersma, T.; Stal, L.J. \& Mur, L.R. (1989): Prochlorothrix hollandica gen. nov., sp. nov., a filamentous oxygenic photoautotrophic procaryote containing chlorophylls a and b: assignment to Prochlorotrichaceae fam. nov. and order Prochlorales Florenzano, Balloni, and Materassi 1986, with emendation of the ordinal description. - Int. J. Syst. Bacteriol. 39: 250-257.

Chu, H. (1952): Some new Myxophyceae from Szechwan province, China. - Ohio J. Sci. 3: 96-101.

da Silva Malone, C.F.; Rigonato, J.; Laughinghouse, H.D.; Schmidt, É.C.; Bouzon, Z.L.; Wilmotte, A.; Fiore, M.F. \& Sant'Anna, C.L. (2015): Cephalothrix gen. nov. (Cyanobacteria): towards an intraspecific phylogenetic evaluation by multilocus analyses. - Int. J. Syst. Evol. Microbiol. 65: 2993-3007.

Desikachary, T.V. (1959): Cyanophyta. - 686 pp., Indian Council of Agricultural Research, New Delhi.

Drummond, A.J.; Ho, S.Y.W.; Philips, M.J. \& Rambaut, A. (2006): Relaxed phylogenetics and dating with confidence. PLoS Biology 4:e88.

DvoŘaK, P.; JaHOdéř́ví, E.; HaŠLER, P.; Gusev, E. \& PoulíčKová, A. (2015): A new tropical cyanobacterium Pinocchia polymorpha gen. et sp. nov. Derived from the genus Pseudanabaena. - Fottea 15: 113-120.

Dvořák, P.; HaŠLER, P.; Pitelková, P.; TABÁKová; P. CASAMATTA, D.A. \& PoulíčKová, A. (2017): A new cyanobacterium from the Everglades, Florida-Chamaethrix gen. nov. - Fottea 17: 269-276.

EKwU, A.O. \& SiKOKI, F.D. (2006): Phytoplankton diversity in the Cross River Estuary of Nigeria. - J. Appl. Sci. Env. Management 10: 89-95

Fiore, M.F.; Sant'Anna, C.L.; de Paiva Azevedo, M.T.; KomáreK, J.; Kaštovský, J.; Sulek, J. \& Lorenzi, A.S. (2007): The cyanobacterial genus Brasilonema, gen. nov., a molecular and phenotypic evaluation. - J. Phycol. 43: 789-798.

GeITLER, L. (1932): Cyanophyceae. - In: RABENHORST, L. (ed.): Kryptogamenflora von Deutschland, Österreich und der Schweiz. - 1196 pp., Akademische Verlagsgesellschaft m. b. H., Leipzig.

Gelman, A. \& Rubin, D.B. (1992): Inference from iterative simulation using multiple sequences. - Statist. Sci. 7: 457-472.

GenuáRIo, D.B.; VAZ, M.G.M.V.; HentschKe, G.S.; SANT'AnNA, C.L. \& Fiore, M.F. (2015): Halotia gen. nov., a phylogenetically and physiologically coherent cyanobacterial genus isolated from marine coastal environments. - Int. J. Syst. Evol. Mic. 65: 663-675

Gomont, M. (1892): Monographie des Oscillariées (Nostocacées homocystées). - Ann. Sci. Nat. Bot., 7 Sér. 15: 263-368.

HeIDARI, F.; HAUER, T.; Zima, J. \& RiAhI, H. (2018): New simple trichal cyanobacterial taxa isolated from radioactive thermal springs. - Fottea 18: 137-149.

Hentschke, G.S.; Johansen, J.R.; Piestrasiak, N.; Fiore, M.F.; Rigonato, J.; Sant'Anna, C.L. \& KomáreK, J. (2016): Phylogenetic placement of Dapisostemon gen. nov. and Streptostemon, two tropical heterocytous genera (Cyanobacteria). - Phytotaxa 245: 129-43.

HentschKe, G.S.; Johansen, J.R.; Piestrasiak, N.; Rigonato, J.; Fiore, M.F. \& SANT'AnNa, C.L. (2017): Komarekiella atlantica gen. et sp. nov. (Nostocaceae, Cyanobacteria): a new subaerial taxon from the Atlantic Rainforest and Kauai, Hawaii. - Fottea 17: 178-190.

JAHODÁŘová, E.; DvořÁK, P.; HAšLeR, P.; Holušová, K. \&
PoulíčKová, A. (2017a): Elainella gen. nov.: a new tropical cyanobacterium characterized using a complex genomic approach. - Euro. J. Phycol. DOI:10.1080/0 9670262.2017.1362591

JAHODÁřová, E.; Dvořák, P.; Hašler, P. \& Poulíckova, A. (2017b): Revealing hidden diversity among tropical cyanobacteria: the new genus Onodrimia (Synechococcales, Cyanobacteria) described using the polyphasic approach. - Phytotaxa 326: 28-40.

Johansen, J.R.; Mareš, J.; Pietrasiak, N.; BohunickÁ, M.; Zima, J.; Štenclová, L. \& Hauer, T. (2017): Highly divergent 16S rRNA sequences in ribosomal operons of Scytonema hyalinum (Cyanobacteria). - PLoS ONE 12: 0186393.

KADIRI, M.O. (2006): Phytoplankton survey in the Western Niger Delta, Nigeria. - Afr. J. Env. Pollut. Health 5: 48-58.

KIM, M.; OH, H.S.; PARK, S.C. \& ChUN, J. (2014): Towards a taxonomic coherence between average nucleotide identity and 16S rRNA gene sequence similarity for species demarcation of prokaryotes. - Int. J. Syst. Evol. Microbiol. 64: 346-351.

KomÁReK, J. \& ANAGNostidis, K. (2005): Cyanoprokaryota II. - In: BÜDEL, B.; KRIENITZ, L.; Gärtner, G. \& Schagerl, M. (eds.): Süsswasserflora von Mittleuropa 19/2. - 759 pp., Elsevier/Spektrum, München.

KomáReK, J.; Kaštovsky, J.; Mareš, J. \& Johansen, J.R. (2014): Taxonomic classification of cyanoprokaryotes (cyanobacterial genera) 2014 according to the polyphasic approach. -Preslia 86: 295-335.

LANE, D.J. (1991): 16S/23S rRNA sequencing. - In: StACKEBRANDT, E. \& Goodfellow, M., (eds): Nucleic acid techniques in bacterial systematics. - pp. 115-175, John Wiley and Sons, New York.

LEY, S.-H. (1947a): New Myxophyceae from Northern Kwangtung. - Bot. Bull. Acad. Sinica 1: 77-79.

LEY, S.-H. (1947b): Heleoplanktonic algae of North Kwangtung. - Bot. Bull. Acad. Sinica 1: 270-282.

LEY, S.-H. (1948): The subaerial algae from the Parcel Islands in the South China Sea. - Bot. Bull. Acad. Sinica 2: 235-242.

LI, X. \& LI, R. (2016): Limnolyngbya circumcreta gen. \& comb. nov. (Synechococcales, Cyanobacteria) with three geographical (provincial) genotypes in China. - Phycologia 55: 478-491.

Martins, M.D. \& Branco, L.H.Z. (2016): Potamolinea gen. nov. (Oscillatoriales, Cyanobacteria): a phylogenetically and ecologically coherent cyanobacterial genus. - Int. J. Syst. Evol. Microbiol. 66: 3632-3641.

Mai, T.; Johansen, J.R.; Pietrasiak, N.; BohunickÁ, M. \& MARTIN, M.P. (2018): Revision of the Synechococcales (Cyanobacteria) through recognition of four families including Oculatellaceae fam. nov. and Trichocoleaceae fam. nov. and six new genera containing 14 species. - Phytotaxa 325: 1-59.

MefFerT, M.-E. (1971): Cultivation and growth of two planktonic Oscillatoria species - Mit. Int. Ver. Limnol. 19: 189-205.

MefFerT, M.-E. (1972): Zur Isolierung von Oscillatoria redekei Van Goor. - Algological Studies 7:235-241.

MEFFERT, M.-E. (1973a): Einflu $\beta$ von $\mathrm{pH}, \mathrm{CO}_{2}-$ Konzentration und Bakterien auf das Wachstum der Blaualge Oscillatoria redekei Van Goor. - Arch. für Hydrobiol. 72:186-201.

MEFFERT, M.-E. (1973b): Kultur und Wachstum von Oscillatoria redekei Van Goor. Zur Bedeutung der Bakterien. -Ver. Int. Ver. Limnol. 18: 1359-1366. 
Meffert, M.-E. (1987): Planktic unsheathed filaments (Cyanophyceae) with polar and central gas vacuoles. - Arch. für Hydrobiol/Supplement 76: 315-346.

MefFERT, M.-E. (1988): Limnothrix Meffert nov. gen. - the unsheathed planktic cyanophycean filaments with polar and central gas vacuoles. - Algological Studies 50-53: 269-276.

MefFert, M.-E \& ChANG, T.P. (1978): The isolation of planktonic blue green algae (Oscillatoria species). - Arch. für Hydrobiol. 82:231-239.

MefFert, M.-E. \& Krambeck, H.J. (1977): Planktic blue-green algae of the Oscillatoria redekei group. - Arch. für Hydrobiol. 82: 231-239.

MefFert, M.-E.; OberhäUSER, R. \& OverbeCK, J. (1982): Morphology and taxonomy of Oscillatoria redekei (Cyanophyta). - Br. Phycol. J. 16:107-114.

MEFFERT, M.-E \& OverBeCK, J. (1981): Interactions between Oscillatoria redekei (Cyanophyta) and bacteria. - Ver. Int. Ver. Limnol. 21:1432-1435.

Miscoe, L.H.; Johansen, J.R.; Vaccarino, M.A.; Pietrasiak, N. \& SHERWOOD, A.R. (2016): Novel cyanobacteria from caves on Kauai, Hawaii. - Bibl. Phycol. 120: 75-152.

Nübel, U.; Garcia-Pichel, F. \& Muyzer, G. (1997): PCR primers to amplify $16 \mathrm{~S}$ rRNA genes from cyanobacteria. - Appl. Environ. Microbiol. 63: 3327-3332.

Nwankwo, D.I. (1988): A preliminary Check-List of planktonic algae of Lagos Lagoon. - Nigerian J. Basic Appl. Sci. 2: 73-85.

NwANKwo, D.I. (1995): Euglenoids of some polluted stormwater channels in Lagos, Nigeria. - Trop. Freshwater Biol. 4: 29-39.

NwANKwo D.I. (1998a): Seasonal changes in phytoplankton population and diversity in Epe lagoon, Nigeria. - Acta Hydrobiol. 10: 83-92.

Nwankwo, D.I. (1998b): The influence of sawmill wood wastes on diatom population at Oko-baba, Lagos, Nigeria. - Nigerian J. Bot. 11: 15-24.

Nwankwo, D.I. \& AkInsoji, A. (1988): Periphyton Algae of eutrophic creek and their possible use as indicator. Nigerian J. Bot. 1: 96-105.

NwANKwo, D.I. \& ONYEMA, I.C. (2003): A checklist of planktonic algae off Lagos coast. - J. Sci. Res. Dev. 9: 75-82.

NwANKwo, D.I. \& ADESALU, T.A. (2010): Notes on Indicators of Environmental Status in Inshore and offshore Waters of South - Western Nigeria. Nat. Sci. 8: 62-65.

Nwankwo, D.I.; Owoseni, T.I.; UsILO, D.A.; OBInYAN, I.; UCHE, A.C. \& ONYEMA, I.C. (2008): Hydrochemistry and plankton dynamics of Kuramo lagoon. - Life Sci. J. 5: 83-88

Nwankwo, D.I.; Chwukwu, L.O.; Osiegbu, G.; Igho-Okor, E. \& ABiola, O. (2014): Effect of waste heat from Egbin thermal plant on the plankton and macrobenthos of Lagos Lagoon. - J. Environ. Ecol. 5: 61-77.

ONUOHA, P.C.; NwANKwo, D.I. \& VyVERMAN, W. (2010): A checklist of phytoplankton species of Ologe Lagoon, Lagos South-Western Nigeria. - J. Am. Sci. 6: 297-302.

ONYEMA, I.C. (2008): A checklist of phytoplankton species of the Iyagbe lagoon, Lagos. - J. Fish Aqua. Sci. 3: 167-175.

Prescott, G.W. (1962): Algae of the Western Great Lakes Area, Revised Edition. - 977 pp., Reprint Otto Koeltz Science Publishers, Königstein, Germany.

RAMBAUT, A. (2007): FigTree. http://tree.bio.ed.ac.uk/software/ figtree/.

Rippka, R.; Waterbury, J. \& COHEN-BAzire, G. (1974): A cyanobacterium which lacks thylakoids. - Arch.
Microbiol. 100: 419-436.

Ronquist, F.; Teslenko, M.; Van Der Mark, P.; Ayres, D. L.; Darling, A.; Hohna, S.; Larget, B.; LiU, L.; SuChard, M. A. \& HuElsenBeCK, J. P. (2012): MrBayes 3.2: Efficient Bayesian phylogenetic inference and model choice across a large model space. Syst. Biol. 61:539-42.

SAnT'AnNa, C.L.; Azevedo, T.M.P.; KaStovskÝ, J. \& KomÁREK, J. (2010): Two form-genera of aerophytic heterocytous cyanobacteria from Brasilian rainy forest "Mata Atlântica”. -Fottea 10: 217-228.

ScIUTO, K. \& Moro, I. (2016): Detection of the new cosmopolitan genus Thermoleptolyngbya (Cyanobacteria, Leptolyngbyaceae) using the 16S rRNA gene and 16S-23S ITS region. - Mol. Phylo. Evol. 105: 15-35.

Sciuto, K.; Moschin, E. \& Moro, I. (2017): Cryptic cyanobacterial diversity in the Giant Cave (Trieste, Italy): the new genus Timaviella (Leptolyngbyaceae). - Cryptogam. Algol. 38: 285-323.

Setchell, W.A. (1924): American Samoa: Part I. Vegetation of Tutuila Island. Part II. Ethnobotany of the Samoas. Part III. Vegetation of Rose Atoll. - Carnegie Institution of Washington Publication No. 341: 275 pp., 37 plates.

Smith, T.E.; Smith, C.J. \& NiI Yemoh Annang, T. (2015): Taxonomic catalogue of algae from Ghana (Africa) and new additions. - 101pp., Ave Maria, Florida, Algae Press.

Song, G.; JiAnG, Y. \& LI, R. (2015): Scytolyngbya timoleontis, gen. et sp. nov. (Leptolyngbyaceae, Cyanobacteria): a novel false branching cyanobacteria form China. Phytotaxa 224: 072-084.

STACKeBRAnDT, E. \& EBERs, J. (2006): Taxonomic parameters revisited: tarnished gold standards. - Microbiol. Today 33: $152-155$.

StackebrandT, E. \& Goebel, B.M. (1994): Taxonomic note: a place for DNA-DNA reassociation and $16 \mathrm{~S}$ rRNA sequence analysis in the present species definition in bacteriology. - Int. J. Syst. Bacteriol. 44: 846-849.

SwOFFord D.L. 1998. PAUP*. Phylogenetic Analysis Using Parsimony (*and other methods). Version 4.02b. Sinauer Associates, Sunderland, MA.

VANLANDingham, S.L. (1982): Guide to the identification and environmental requirements and pollution tolerance of freshwater blue-green algae (cyanophyta). - U.S. Environ. Protection Agency. 60.

Vaz, M.G.G.V.; Genuário, D.B.; Andreote, A.P.D.A.; Malone, C.F.S.; SAnt'AnNA, A.L. \& Fiore, M.F. (2015): Pantanalinema gen. nov. and Alkalinema gen. nov.: novel pseudanabaenacean genera (Cyanobacteria) isolated from saline-alkaline lakes. - Int. J. Syst. Evol. Microbiol. 65: 298-308.

VÁZqueZ-MartíneZ, J.; Gutierrez-VillagomeZ, J.M.; Fonesca-García, C.; RAMÍreZ-Chávez, E.; Mondragón-SÁnchez, M.L.; PARTida-Martínez, L.; Johansen, J.R. \& Molina-Torres, J. (2018): Nodosilinea chupicuarensis sp. nov. (Leptolyngbyaceae, Synechococcales) a subaerial cyanobacterium isolated from a stone monument in central Mexico. - Phytotaxa 334:167-182.

Werner, V.R.; SANT'AnNA, C.L. \& Azevdo, M.T.P. (2008): Cyanoaggregatum brasiliense gen. et sp. nov., a new chroococcal Cyanobacteria from Southern Brasil. Rev. Bras. Bot. 31: 491-497.

Whitford, L.A. \& SCHUMACHER, G.J. (1984): A manual of fresh-water algae. -337 pp., Sparks Press, Raleigh, N.C.

Whitton, B.A. (2011): Cyanobacteria (Cyanophyta). - In: 
John, D.M.; WhitTon, B.A. \& Brook, A.J. (eds.): The freshwater algal flora of the British Isles. An identification guide to freshwater and terrestrial algae. Second edition, - pp. 31-158, Cambridge University Press, Cambridge.

Wilmotte, A.; Van der auwera, G. \& De wachter, R. (1993): Structure of the 16S ribosomal RNA of the thermophilic cyanobacterium Chlorogloeopsis HTF (Mastigocladus laminosus HTF) strain PCC7518 and phylogenetic analysis. - FEBS Letters 317: 96-100.

Yarza, P.; Yilmaz, P.; Pruesse, E.; GlÖcKNer, F.O.; LudwiG, W.; Schleifer, K.; Whitman, W.B.; Euzéby, J.; Amann, R. \& Rosselló-Móra, R. (2014): Uniting the classification of cultured and uncultured bacteria and archaea using 16S rRNA gene sequences. - Nature Rev. Microbiol. 12: 635-645.

Yoneda, Y. (1938a): Cyanophyceae of Japan, II. - Acta Phytotaxon Geobot. 7: 88-101.

YonedA, Y. (1938b): Cyanophyceae of Japan, III. - Acta Phytotaxon Geobot. 7: 139-183.

Yoneda, Y. (1939): Cyanophyceae of Japan, IV. - Acta Phytotaxon Geobot. 8: 32-49.

Yoneda, Y. (1940): Cyanophyceae of Japan, V. - Acta Phytotaxon Geobot. 9: 39-50.

YonedA, Y. (1941): Cyanophyceae of Japan, VI. - Acta Phytotaxon Geobot. 10: 38-53.
ZHU, M.; YU, G. ; LI, X.; TAN, W. \& LI, R. (2012): Taxonomic and phylogenetic evaluation of Limnothrix strains (Oscillatoriales, Cyanobacteria) by adding Limnothrix planctonica strains isolated from central China. Hydrobiol. 698: 367-374.

ZuKer, M. (2003): Mfold web server for nucleic acid folding and hybridization prediction. -Nucleic Acids Res. 31: 3406-3415.

Supplementary material

the following supplementary material is available for this article:

Fig. S1. Uncollapsed Bayesian Inference phylogeny based on 313 partial sequences of the $16 \mathrm{~S}$ rRNA gene.

This material is available as part of the online article (http:// fottea.czechphycology.cz/contents)

(C) Czech Phycological Society (2019)

Received February 27, 2018

Accepted September 4, 2018 